University of Nebraska - Lincoln

DigitalCommons@University of Nebraska - Lincoln

Robert G. Fuller Publications and Presentations Research Papers in Physics and Astronomy

December 1980

Improving physics teaching

Robert Fuller

rfuller@neb.rr.com

Follow this and additional works at: https://digitalcommons.unl.edu/physicsfuller

Part of the Physics Commons

Fuller, Robert, "Improving physics teaching" (1980). Robert G. Fuller Publications and Presentations. 32. https://digitalcommons.unl.edu/physicsfuller/32

This Article is brought to you for free and open access by the Research Papers in Physics and Astronomy at DigitalCommons@University of Nebraska - Lincoln. It has been accepted for inclusion in Robert G. Fuller Publications and Presentations by an authorized administrator of DigitalCommons@University of Nebraska - Lincoln. 


\section{Improving physics teaching}

began this editorial with a desire to take up battle against the recent ills of physics teaching. I paused to peruse the AAPT reprint book, 50 Years on Teaching Physics, edited by Melba Phillips.

Wow! It's all been said before. The recent ills aren't recent. Most of them were exposed and discussed many years ago.

"It is no exaggeration to say that 90 percent of students of physics are in elementary classes and teachers spend 70 percent of their teaching time with them." (Osgood, 1940)

“There was a lot of talk in the 1930's to the effect that no man could be a good teacher, even in undergraduate classes, unless he was also a researcher ... It had seemed to justify a rule that each faculty member would be judged entirely by his reseach (meaning subject-matter research, as usual, and strictly excluding research on how to teach his subject) and there would be no promotions except on this basis." (Webster, 1956)

"Most of our students have come up from childhood without ever being placed under the care of an untrained teacher until they begin to meet such in university physics and chemistry laboratories and quiz sections... Is it too much to hope that universities will some day relieve the graduate student of his teaching duties, put a better qualified teacher in his place, and then-in case the graduate student really wants to learn about college-level teaching-do something serious about training him?"' (Kirkpatrick, 1958)

So history suggests that the weaknesses in physics teaching are persistent. They never seem to change and they never seem to go away. But I would like to call attention to some new developments in teaching that hold out the promise that some of these weaknesses could be corrected well before another fifty years have passed.

I believe that today most physicists still treat teaching as an art-in fact, an art with no physical observables. Physics professors do not observe the teaching of others nor want their own teaching observed. However, the impact of the scientific study of learning is beginning to influence physics teaching. I think it began first with the reinforcement theory of learning and the Keller Plan in the early 1970's. This plan codified the experience of many good teachers that frequent testing and immediate feedback about performance greatly enhances student learning. So far, the Keller Plan influence has been small. The use of computers may eventually reduce the work required to use the Keller Plan and then its use should become more widespread. A second influence from a scientific study of learning is the growing interest in the work of Jean Piaget. Piaget's classic study of student reasoning using physics experiments in a clinical-interview setting has struck the fancy of physicists. Now physicists, more than any other professionals, are trying to explore the implications of Piaget's work in their teaching. A third area of scientific study is the social climate professors establish in their classrooms. Research on self-fulfilling prophecies is now being translated into guides for classroom behavior: Consider the physics teachers who say, "My course is tough. If you are a typical class half of you won't be with me at the end of the semester." What are those teachers expecting to happen? What do they do to see those expectations fulfilled?

Another major challenge is how to break the lecture-recitation-laboratory stranglehold on the format of physics teaching. Educational research shows some parts of the format are not effective teaching methods. Can we find better methods?

The present technological revolution may help us answer this question. The decreasing cost and increasing power of personal computers are already beginning to have some influence in the physics classroom. The potential educational value of the random-access videodisc plus personal computer, the socalled intelligent videodisc system, is incredible.

But the good fruits of the growth of the scientific study of learning and of educational technology will not be useful to physics teaching without a strong commitment. University physics departments are going to have to devote considerable faculty time to make these fruits available for teaching.

The American Association of Physics Teachers has been actively encouraging physicists to improve their teaching skills by taking advantage of the results of scientific learning studies and educational technology. While still maintaining its role as a publisher of journals for physicists with teaching interests, it has a vigorous program of workshops. AAPT workshops, such as ones on the Keller Plan, Piaget's work, student confidence in physics, programmable calculators, and microprocessors, are offered at national and regional meetings.

I see some evidence that physics departments are beginning to respond. Departments are hiring young physicist-teacher practitioners to improve the teaching in their departments. This is a first step towards redressing the current imbalance between the rewards for doing research in physics content versus research in physics teaching.

But for these beginnings to evolve into a full-scale revision of teaching methods, the efforts of AAPT will need to be augmented by the strong support of the entire physics community and the relevant federal agencies. Science literacy seems to have reached an all-time low. It is particularly urgent for physicists to take a leadership role in improving the way science is taught.

ROBERT G. FULLER President American Association of Physics Teachers 